\title{
Update: Interim Guidance for Preconception Counseling and Prevention of Sexual Transmission of Zika Virus for Persons with Possible Zika Virus Exposure - United States, September 2016
}

\begin{abstract}
Emily E. Petersen, $\mathrm{MD}^{1}$; Dana Meaney-Delman, $\mathrm{MD}^{1}$; Robyn Neblett-Fanfair, $\mathrm{MD}^{1}$; Fiona Havers, $\mathrm{MD}^{1}$; Titilope Oduyebo, $\mathrm{MD}^{1}$; Susan L. Hills, MBBS ${ }^{1}$; Ingrid B. Rabe, MBChB ${ }^{1}$; Amy Lambert, PhD ${ }^{1}$; Julia Abercrombie, MPH ${ }^{1}$; Stacey W. Martin, MSc ${ }^{1}$; Carolyn V. Gould, MD ${ }^{1}$; Nadia Oussayef, JD ${ }^{1}$; Kara N.D. Polen, $\mathrm{MPH}^{1}$; Matthew J. Kuehnert, $\mathrm{MD}^{1}$; Satish K. Pillai, MD ${ }^{1}$; Lyle R. Petersen, MD ${ }^{1}$; Margaret A. Honein, PhD ${ }^{1}$; Denise J. Jamieson, $\mathrm{MD}^{1}$; John T. Brooks, $\mathrm{MD}^{1}$
\end{abstract}

On September 30, 2016, this report was posted as an MMWR Early Release on the MMWR website (http://www.cdc.gov/mmwr).

CDC has updated its interim guidance for persons with possible Zika virus exposure who are planning to conceive (1) and interim guidance to prevent transmission of Zika virus through sexual contact (2), now combined into a single document. Guidance for care for pregnant women with possible Zika virus exposure was previously published (3). Possible Zika virus exposure is defined as travel to or residence in an area of active Zika virus transmission (http://www.cdc.gov/zika/geo/ index.html), or sex* without a condom ${ }^{\dagger}$ with a partner who traveled to or lived in an area of active transmission. Based on new though limited data, CDC now recommends that all men with possible Zika virus exposure who are considering attempting conception with their partner, regardless of symptom status, ${ }^{\mathfrak{S}}$ wait to conceive until at least 6 months after symptom onset (if symptomatic) or last possible Zika virus exposure (if asymptomatic). Recommendations for women planning to conceive remain unchanged: women with possible Zika virus exposure are recommended to wait to conceive until at least 8 weeks after symptom onset (if symptomatic) or last possible Zika virus exposure (if asymptomatic). Couples with possible Zika virus exposure, who are not pregnant and do not plan to become pregnant, who want to minimize their risk for sexual transmission of Zika virus should use a condom or abstain from sex for the same periods for men and women described above. Women of reproductive age who have had or anticipate future Zika virus exposure who do not want to become pregnant should use the most effective contraceptive method that can be used correctly and consistently. These recommendations will be further updated when additional data become available.

\footnotetext{
${ }^{*}$ For the purpose of this guidance, sex is specifically defined as vaginal sex (penisto-vagina sex), anal sex (penis-to-anus sex), oral sex (mouth-to-penis sex or mouth-to-vagina sex), and the sharing of sex toys.

† Condoms include the use of male or female condoms for vaginal or anal sex, male condoms for oral sex (mouth-to-penis), and male condoms cut to create a flat barrier or dental dams for oral sex (mouth-to-vagina).

$\S$ A person is considered symptomatic if one or more signs or symptoms (acute onset of fever, rash, arthralgia, or conjunctivitis) consistent with Zika virus disease is reported. A person is considered asymptomatic if these symptoms are not reported.
}

\section{Review of Evidence}

Zika virus infection during pregnancy is a cause of congenital microcephaly and serious brain abnormalities (4). The risk for adverse pregnancy outcomes associated with maternal Zika virus infection around the time of conception is unknown. To date, there have been no published reports of adverse pregnancy outcomes after periconceptional Zika virus infection. Infections with other viruses (e.g., cytomegalovirus, rubella, parvovirus) around the time of conception have been associated with congenital infection and adverse pregnancy outcomes, although the exact timing of infection relative to conception was sometimes uncertain (5-9).

Zika virus is transmitted primarily through the bite of Aedes aegypti mosquitoes. Zika virus can also be transmitted through sex without a condom. The risk for sexual transmission of Zika virus from a person infected with Zika virus remains unknown. Most reported sexual transmissions have been from persons with symptomatic Zika virus infections, including from men to female sex partners (10-12), from a man to his male sex partner (13), and from a woman to her male sex partner (14). Two new reports describe one presumed and one more definitive case of sexual transmission from men with asymptomatic Zika virus infection to female sex partners $(15,16)$. Sexual transmission of Zika virus has been associated with condomless anal sex and vaginal sex and possibly also with fellatio (17). Among reported cases of sexually transmitted Zika virus infection, the longest reported period between sexual contact that might have transmitted Zika virus and symptom onset was 32-41 days (based on an incubation period of 3-12 days) (18).

Data on the detection of Zika virus RNA in semen can inform estimates of the periods during which sexual transmission might occur. However, detection of Zika virus RNA in semen might not indicate the presence of infectious virus and thus the potential for sexual transmission. Reports indicate that concentrations of detectable Zika virus RNA in semen decrease after infection (17,19-28). Zika virus RNA was detected in semen of five men more than 90 days after symptom onset, 
with the longest period of reported detection 188 days after symptom onset $(20,26,29,30)$. Culture is considered the gold standard for demonstrating the presence of replicative and thus infectious virus, and among four published reports of Zika virus cultured from semen, virus was reported in semen up to 69 days after symptom onset $(17,19,21,31)$. Culture methods varied in these studies and additional studies are needed to confirm the presence of infectious virus in semen.

New data on the persistence of Zika virus RNA in serum and whole blood might have implications, both for sexual transmission of Zika virus and for fetal exposure to Zika virus. Zika virus RNA has been detected in the serum of nonpregnant persons up to 11-13 days after symptom onset (32); in the serum of pregnant women, Zika virus RNA has been detected up to 10 weeks after symptom onset $(33,34)$. Zika virus RNA was detected in whole blood of a nonpregnant person up to 58 days after symptom onset followed by a negative result at 79 days; however, Zika virus could not be cultured at 58 days (35). Experience with other flaviviruses suggests that if a person's immune system has activated an antibody response, viral transmission (i.e., through blood transfusion) is unlikely (36). Detection of Zika virus RNA in blood might not indicate the presence of infectious virus, and thus the potential risk for maternal-fetal Zika virus transmission periconceptionally is unknown.

\section{Guidance for Preconception Counseling and Prevention of Sexual Transmission}

CDC is updating its guidance on timing of conception after possible Zika virus exposure and prevention of sexual transmission of Zika virus. CDC continues to evaluate all available evidence and update recommendations as new data become available. Most of the recommendations for preconception counseling and prevention of sexual transmission are dependent on whether persons live in or travel to areas of active Zika virus transmission. As of September 26, 2016, 59 countries and U.S. territories reported active Zika virus transmission. The Florida Department of Health identified two areas of Miami-Dade County with active local mosquitoborne Zika virus transmission; as of September 20, 2016, only one remains an area of active transmission (37). Updates on areas with active Zika virus transmission are available online at http://www.cdc.gov/zika/geo/index.html.

For Couples Planning to Conceive Who Do Not Live in Areas with Active Zika Virus Transmission. Health care providers should discuss couples' travel plans in preconception counseling. Women and men who are planning to conceive in

\footnotetext{
Sttp://www.cdc.gov/zika/geo/index.html.
}

the near future should consider avoiding nonessential travel to areas with active Zika virus transmission.

Women who have had possible Zika virus exposure through travel or sexual contact and do not have ongoing risks for exposure should wait at least 8 weeks from symptom onset (if symptomatic) or last possible exposure (if asymptomatic) to attempt conception. Women who wait at least 8 weeks to conceive might have an increased likelihood that Zika virus no longer presents a risk for maternal-fetal transmission.

CDC now recommends that men with possible Zika virus exposure, regardless of symptom status, wait at least 6 months from symptom onset (if symptomatic) or last possible exposure (if asymptomatic) before attempting conception with their partner. CDC previously recommended that men with possible Zika virus exposure who were asymptomatic wait at least 8 weeks from last possible exposure. The updated recommendation minimizes the likelihood that periconceptional sexual transmission will result in fetal exposure to Zika virus. The recommendation to wait at least 6 months for asymptomatic men is based on the range of time after symptom onset that Zika virus RNA has been detected in semen of symptomatic men and the absence of definitive data that the risk for sexual transmission differs between symptomatic and asymptomatic men. Zika virus has not been definitively cultured from semen more than 3 months after symptom onset. It is unknown whether detection of Zika virus RNA in semen indicates presence of infectious virus and the potential for transmission. Current recommendations provide couples planning to conceive with periods that, based on existing data, are expected to minimize risk for Zika virus transmission to an uninfected partner. Studies are underway to better understand the persistence of infectious Zika virus in semen and the associated risk for sexual transmission of the virus. Given that limited data are available, some couples in whom a partner had possible Zika virus exposure might choose to wait longer or shorter than the recommended period to conceive, depending on individual circumstances (e.g., age, fertility, details of possible exposure) and risk tolerance. For example, after consultation with their health care provider, symptomatic persons with negative test results who received testing in the appropriate time window and in accordance with the testing algorithm (38) might choose not to wait to conceive.

For Couples Who Want to Conceive, in Which One or Both Partners Live in Areas with Active Zika Virus Transmission. Women and men who reside in areas with active Zika virus transmission and who experience symptoms of Zika virus disease should be tested for Zika virus infection (38). Men with results that indicate recent Zika virus or unspecified flavivirus infection should wait at least 6 months from symptom 
onset to attempt conception with their partner; women with results that indicate recent Zika virus or unspecified flavivirus infection should wait at least 8 weeks from symptom onset to attempt conception. Persons who have had symptoms of Zika virus disease with negative Zika virus test results should talk with their health care provider about timing of conception in the setting of ongoing risk for possible exposure.

Persons living in an area with active Zika virus transmission should be counseled on the possible risk for Zika virus infection during the periconception period. CDC has developed tools to assist health care providers with preconception counseling (39). Health care providers should provide counseling about the potential consequences to the fetus associated with Zika virus infection during pregnancy, such as microcephaly and other serious brain abnormalities. Women and men should discuss their reproductive life plans** with their health care provider, in the context of potential and ongoing Zika virus exposure. Health care providers should review factors that might influence pregnancy timing (e.g., unknown duration of Zika virus outbreak, fertility, age, reproductive history, medical history, personal values and preferences). For couples who choose to conceive, health care providers should stress use of mosquito bite prevention strategies ${ }^{\dagger \dagger}$ while attempting pregnancy and during pregnancy. Health care providers should counsel couples who decide to wait to attempt conception about strategies to prevent unintended pregnancy, including the most effective contraceptive methods (i.e., long-acting reversible contraception) and provide contraception or referral to appropriate providers for contraception care (40).

Special Considerations for Women Undergoing Fertility Treatment. Zika virus transmission through assisted reproductive technology has not been reported. However, transmission through gametes or embryos is theoretically possible. Recommendations for sexually intimate couples with Zika virus infection or possible Zika virus exposure undergoing fertility treatment with their own gametes and embryos should follow the testing and timing recommendations as described above; recommendations might need to be adjusted depending on individual circumstances and risk tolerance. The Food and Drug Administration has issued guidance to reduce the risk for Zika virus transmission by donated human cells, tissues, and cellular and tissue-based products, including reproductive tissues (41).

For Couples Who Are Not Pregnant and Are Not Planning to Become Pregnant in the Near Future. Couples in whom the man or woman has had possible Zika virus exposure who want to maximally reduce their risk for sexually transmitting

\footnotetext{
** http://www.cdc.gov/preconception/reproductiveplan.html.

$\dagger^{\dagger}$ https://www.cdc.gov/zika/prevention/prevent-mosquito-bites.html.
}

Zika virus to the uninfected partner should use condoms consistently and correctly or abstain from sex for at least 6 months for men or 8 weeks for women after symptom onset (if symptomatic) or last possible Zika virus exposure (if asymptomatic). Some couples might choose to use condoms or abstain from sex for a shorter or longer period than recommended depending on individual circumstances. Couples should be advised that correct and consistent use of condoms reduces the risk for other sexually transmitted infections.

Health care providers should discuss strategies to prevent unintended pregnancy with couples who do not want to become pregnant. Safety, effectiveness, availability, and acceptability should be considered when choosing a contraceptive method (42). Patients should be counseled to use the most effective contraceptive method that can be used correctly and consistently. Long-acting reversible contraception, including contraceptive implants and intrauterine devices, provide highly effective reversible options.

For Pregnant Women and Their Partners. Pregnant women living in areas without active Zika virus transmission should be advised to avoid nonessential travel to areas with active transmission. Persons who have traveled to or live in an area with active Zika virus transmission and whose partner is pregnant should be advised to consistently and correctly use condoms during sex or abstain from sex for the duration of the pregnancy. These actions reduce the risk for sexual transmission of Zika virus during pregnancy. Health care providers should ask pregnant women about their own and their sex partner's history of travel to areas with active Zika virus transmission. Pregnant women with possible Zika virus exposure, either through sex or through traveling to or living in an area with active Zika virus transmission, should be tested for Zika virus infection in accordance with CDC's "Updated Interim Pregnancy Guidance: Testing and Interpretation Recommendations for a Pregnant Women with Possible Exposure to Zika Virus" (http://www.cdc.gov/zika/pdfs/ testing_algorithm.pdf), including pregnant women with possible sexual exposure whose sex partner has had no symptoms of Zika virus disease. Further guidance for care of pregnant women with possible Zika virus exposure has been published (3).

\section{Zika Virus Testing}

Persons with possible Zika virus exposure who have symptoms of Zika virus disease should receive testing in accordance with CDC interim guidance: "Algorithm for U.S. Testing of Symptomatic Individuals" (38). CDC does not recommend Zika virus testing of nonpregnant persons with possible Zika virus exposure who do not have symptoms of Zika virus disease, including persons who are planning to attempt conception, or to assess the risk for sexual transmission of Zika virus. Zika virus testing for this purpose remains of uncertain value, because 
current understanding of the duration and pattern of shedding of $\mathrm{Zika}$ virus in reproductive tissues is limited. Information on the performance of serologic Zika virus testing remains limited, with falsely positive tests resulting in avoidable stress and expense and falsely negative tests providing false reassurance and possibly leading to inadvertent fetal exposure to Zika virus.

1Zika Response, CDC.

Corresponding author: Emily E. Petersen; zikamch@cdc.gov; 770-488-7100.

\section{References}

1. Petersen EE, Polen KN, Meaney-Delman D, et al. Update: interim guidance for health care providers caring for women of reproductive age with possible Zika virus exposure-United States, 2016. MMWR Morb Mortal Wkly Rep 2016;65:315-22. http://dx.doi.org/10.15585/mmwr. $\mathrm{mm} 6512 \mathrm{e} 2$

2. Brooks JT, Friedman A, Kachur RE, LaFlam M, Peters PJ, Jamieson DJ. Update: interim guidance for prevention of sexual transmission of Zika virus-United States, July 2016. MMWR Morb Mortal Wkly Rep 2016;65:745-7. http://dx.doi.org/10.15585/mmwr.mm6529e2

3. Oduyebo T, Igbinosa I, Petersen EE, et al. Update: interim guidance for health care providers caring for pregnant women with possible Zika virus exposure-United States, July 2016. MMWR Morb Mortal Wkly Rep 2016;65:739-44. http://dx.doi.org/10.15585/mmwr.mm6529e1

4. Rasmussen SA, Jamieson DJ, Honein MA, Petersen LR. Zika virus and birth defects - reviewing the evidence for causality. N Engl J Med 2016;374:1981-7. http://dx.doi.org/10.1056/NEJMsr1604338

5. Daiminger A, Bäder U, Enders G. Pre- and periconceptional primary cytomegalovirus infection: risk of vertical transmission and congenital disease. BJOG 2005;112:166-72. http://dx.doi. org/10.1111/j.1471-0528.2004.00328.x

6. Enders G, Miller E, Nickerl-Pacher U, Cradock-Watson JE. Outcome of confirmed periconceptional maternal rubella. Lancet 1988;331:1445-7. http://dx.doi.org/10.1016/S0140-6736(88)92249-0

7. Picone O, Vauloup-Fellous C, Cordier AG, et al. A series of 238 cytomegalovirus primary infections during pregnancy: description and outcome. Prenat Diagn 2013;33:751-8. http://dx.doi.org/10.1002/pd.4118

8. Revello MG, Zavattoni M, Furione M, Lilleri D, Gorini G, Gerna G. Diagnosis and outcome of preconceptional and periconceptional primary human cytomegalovirus infections. J Infect Dis 2002;186:553-7. http:// dx.doi.org/10.1086/341831

9. Nunoue T, Kusuhara K, Hara T. Human fetal infection with parvovirus B19: maternal infection time in gestation, viral persistence and fetal prognosis. Pediatr Infect Dis J 2002;21:1133-6. http://dx.doi. org/10.1097/00006454-200212000-00009

10. Foy BD, Kobylinski KC, Chilson Foy JL, et al. Probable non-vectorborne transmission of Zika virus, Colorado, USA. Emerg Infect Dis 2011;17:880-2 http://dx.doi.org/10.3201/eid1705.101939.

11. Hills SL, Russell K, Hennessey M, et al. Transmission of Zika virus through sexual contact with travelers to areas of ongoing transmissionContinental United States, 2016. MMWR Morb Mortal Wkly Rep 2016;65:215-6. http://dx.doi.org/10.15585/mmwr.mm6508e2

12. Venturi G, Zammarchi L, Fortuna C, et al. An autochthonous case of Zika due to possible sexual transmission, Florence, Italy, 2014. Euro Surveill 2016;21:30148. http://dx.doi.org/10.2807/1560-7917. ES.2016.21.8.30148

13. Deckard DT, Chung WM, Brooks JT, et al. Male-to-male sexual transmission of Zika virus-Texas, January 2016. MMWR Morb Mortal Wkly Rep 2016;65:372-4. http://dx.doi.org/10.15585/mmwr.mm6514a3
14. Davidson A, Slavinski S, Komoto K, Rakeman J, Weiss D. Suspected female-to-male sexual transmission of Zika virus-New York City, 2016. MMWR Morb Mortal Wkly Rep 2016;65:716-7. http://dx.doi. org/10.15585/mmwr.mm6528e2

15. Fréour T, Mirallié $S$, Hubert B, et al. Sexual transmission of Zika virus in an entirely asymptomatic couple returning from a Zika epidemic area, France, April 2016. Euro Surveill 2016;21:30254. http://dx.doi. org/10.2807/1560-7917.ES.2016.21.23.30254

16. Brooks RB, Carlos MP, Myers RA, et al. Likely sexual transmission of Zika virus from a man with no symptoms of infection-Maryland, 2016. MMWR Morb Mortal Wkly Rep 2016;65:915-6. http://dx.doi. org/10.15585/mmwr.mm6534e2

17. D'Ortenzio E, Matheron S, de Lamballerie X, et al. Evidence of sexual transmission of Zika virus. N Engl J Med 2016;374:2195-8. http:// dx.doi.org/10.1056/NEJMc1604449

18. Turmel JM, Abgueguen P, Hubert B, et al. Late sexual transmission of Zika virus related to persistence in the semen. Lancet 2016;387:2501. http://dx.doi.org/10.1016/S0140-6736(16)30775-9

19. Musso D, RocheC, Robin E, NhanT, TeissierA, Cao-Lormeau VM. Potential sexual transmission of Zika virus. Emerg Infect Dis 2015;21:359-61. http://dx.doi.org/10.3201/eid2102.141363

20. Mansuy JM, Suberbielle E, Chapuy-Regaud S, et al. Zika virus in semen and spermatozoa. Lancet Infect Dis 2016;16:1106-7. http://dx.doi. org/10.1016/S1473-3099(16)30336-X

21. Mansuy JM, Dutertre M, Mengelle $C$, et al. Zika virus: high infectious viral load in semen, a new sexually transmitted pathogen? Lancet Infect Dis 2016;16:405. http://dx.doi.org/10.1016/S1473-3099(16)00138-9

22. Atkinson B, Hearn P, Afrough B, et al. Detection of Zika virus in semen. Emerg Infect Dis 2016;22:940. http://dx.doi.org/10.3201/ eid2205.160107

23. Reusken C, Pas S. GeurtsvanKessel C, et al. Longitudinal follow-up of Zika virus RNA in semen of a traveller returning from Barbados to the Netherlands with Zika virus disease, March 2016. Euro Surveill 2016;21:30251. http:// dx.doi.org/10.2807/1560-7917.ES.2016.21.23.30251

24. Matheron S, d'Ortenzio E, Leparc-Goffart I, Hubert B, de Lamballerie X, Yazdanpanah Y. Long-lasting persistence of Zika virus in semen. Clin Infect Dis 2016. E-pub July 28, 2016. http://dx.doi.org/10.1093/cid/ciw509

25. Harrower J, Kiedrzynski T, Baker S, et al. Sexual transmission of Zika virus and persistence in semen, New Zealand, 2016. Emerg Infect Dis 2016;22:1855-7. http://dx.doi.org/10.3201/eid2210.160951

26. Mansuy JM, Pasquier C, Daudin M, et al. Zika virus in semen of a patient returning from a non-epidemic area. Lancet Infect Dis 2016;16:894-5. http://dx.doi.org/10.1016/S1473-3099(16)30153-0

27. Frank C, Cadar D, Schlaphof A, et al. Sexual transmission of Zika virus in Germany, April 2016. Euro Surveill 2016;21:30252. http://dx.doi. org/10.2807/1560-7917.ES.2016.21.23.30252

28. Huits B, Arien KK, Van Esbroeck M, de Jong BC, Bottieau E, Cnops L. Kinetics of Zika virus persistence in semen. Bull World Health Organ 2016. E-pub July 6, 2016. http://www.who.int/bulletin/online_ first/16-181370.pdf

29. Barzon L, Pacenti M, Franchin E, et al. Infection dynamics in a traveller with persistent shedding of Zika virus RNA in semen for six months after returning from Haiti to Italy, January 2016. Euro Surveill 2016;21:30316. 10.2807/1560-7917.ES.2016.21.32.30316

30. Nicastri E, Castilletti C, Liuzzi G, Iannetta M, Capobianchi MR, Ippolito G. Persistent detection of Zika virus RNA in semen for six months after symptom onset in a traveller returning from Haiti to Italy, February 2016. Euro Surveill 2016;21:30314. http://dx.doi. org/10.2807/1560-7917.ES.2016.21.32.30314

31. Arsuaga M, Bujalance SG, Díaz-Menéndez M, Vázquez A, Arribas JR. Probable sexual transmission of Zika virus from a vasectomised man. Lancet Infect Dis 2016;16:1107. http://dx.doi.org/10.1016/ S1473-3099(16)30320-6 
32. Lanciotti RS, Kosoy OL, Laven JJ, et al. Genetic and serologic properties of Zika virus associated with an epidemic, Yap State, Micronesia, 2007. Emerg Infect Dis 2008;14:1232-9. http://dx.doi.org/10.3201/ eid1408.080287

33. Driggers RW, Ho CY, Korhonen EM, et al. Zika virus infection with prolonged maternal viremia and fetal brain abnormalities. N Engl J Med 2016;374:2142-51. http://dx.doi.org/10.1056/NEJMoa1601824

34. Meaney-Delman D, Oduyebo T, Polen KN, et al.; U.S. Zika Pregnancy Registry Prolonged Viremia Working Group. Prolonged detection of Zika virus RNA in pregnant women. Obstet Gynecol 2016;128:724-30. http://dx.doi.org/10.1097/AOG.0000000000001625

35. Lustig Y, Mendelson E, Paran N, Melamed S, Schwartz E. Detection of Zika virus RNA in whole blood of imported Zika virus disease cases up to 2 months after symptom onset, Israel, December 2015 to April 2016. Euro Surveill 2016;21:30269. http://dx.doi.org/10.2807/1560-7917. ES.2016.21.26.30269

36. Busch MP, Kleinman SH, Tobler LH, et al. Virus and antibody dynamics in acute West Nile virus infection. J Infect Dis 2008;198:984-93. http:// dx.doi.org/10.1086/591467

37. CDC. CDC updates guidance for travel and testing of pregnant women and women of reproductive age for Zika virus infection related to the ongoing investigation of local mosquito-borne Zika virus transmission in Miami-Dade County, Florida. Atlanta, GA: US Department of Health and Human Services, CDC; 2016. https://emergency.cdc.gov/han/ han00396.asp
38. CDC. Guidance for U.S. laboratories testing for Zika virus infection. Atlanta, GA: US Department of Health and Human Services, CDC; 2016. http://www.cdc.gov/zika/laboratories/lab-guidance.html

39. CDC. Preconception counseling for women and men living in areas with ongoing spread of Zika virus who are interested in conceiving. Atlanta, GA: US Department of Health and Human Services, CDC; 2016. https://www.cdc.gov/zika/pdfs/preconception-counseling.pdf

40. CDC. Effectiveness of family planning methods. Atlanta, GA: US Department of Health and Human Services, CDC; 2016. https://www. cdc.gov/reproductivehealth/unintendedpregnancy/pdf/contraceptive_ methods_508.pdf

41. Food and Drug Administration. Donor screening recommendations to reduce the risk of transmission of Zika virus by human cells, tissues, and cellular and tissue-based products. Silver Spring, MD: US Department of Health and Human Services, Food and Drug Administration; 2016. http://www.fda.gov/downloads/BiologicsBloodVaccines/ GuidanceComplianceRegulatoryInformation/Guidances/Tissue/ UCM488582.pdf

42. Curtis KM, Jatlaoui TC, Tepper NK, et al. U.S. selected practice recommendations for contraceptive use, 2016. MMWR Recomm Rep 2016;65(No. RR-4). http://dx.doi.org/10.15585/mmwr.rr6504a1 